ISBN-978-93-86878-24-3

15th LISBON - PORTUGAL International Conference on "Business, Humanities, Education and

Social Sciences" (LBHESS-18)

Lisbon (Portugal) Dec. 17-19, 2018

\title{
Tracing Patterns of Melodrama: On Almodovar's All About My Mother
}

\author{
Pelin Aytemiz ${ }^{1}$ \\ ${ }^{1}$ Associate Professor, Başkent University, Faculty of Communication, Turkey \\ (Email: paytemiz@baskent.edu.tr)
}

\begin{abstract}
This paper tries to articulate what is typically melodramatic in Pedro Almodovar's Oscar winning film All About My Mother (Todo Sobre Mi Madre, 1999). To what extent the film can be considered as in the scope of the genre? What are the subversive parts, which fall out the margins of Conventional Hollywood Melodramas? In order to elaborate on these questions, the article pinpoints features of Classical Hollywood Melodrama, traces patterns of the genre and examines "iconography" and "narrative" of All About My Mother. The article suggests that there is a special and ironic treatment of the genre melodrama. It argues that Almodovar re-contextualize the Hollywood Melodrama genre and uses it as a tool to subvert issues about gender formulation and social roles specific to patriarchal societies. The article uses Judith Butler's concepts of "performance" and "performativity" and Hutchens's understanding of "parody" in order to explain the way the director subverts issues on conventional gender positioning and roles in the society
\end{abstract}

Keywords: Almodovar, melodrama, All About My Mother, genre, gender, parody, excess.

\section{Introduction}

According to Gledhill, in the early 20th century the genre melodrama was denigrated by film theorists and was conceived as an invaluable arena to be studied. The field of attention in film studies was dominantly on realism and tragedy. Film studies discovered melodrama as an arena of study only after 1960's. In this discovery the role of the auteur director Douglas Sirk cannot be denied. His films took the attention of film critics and their attention is further directed to the genre of melodrama. By the realization of irony and parody in Sirk's films the question for the critics became, can melodrama be read as a subversive and critical form? (Gledhill, 1987). Sirk also had an influence on filmmakers such as the Spanish director Pedro Almodovar. This paper particularly focuses on melodramatic patterns in Almodovar's cinema focusing on All About My Mother (Todo Sobre Mi Madre, 1999). To what extent Almodovar's All About My Mother can be considered as melodrama and what are the subversive parts, which fall out the margins of conventional Hollywood Melodramas, is the question this article is curious of. Depending on Gledhill (1987) one can say that there are two constituents that determine the genre of a film which are, (a) the narrative and (b) the iconography. While analyzing the iconography of the film I will be focusing the founding element of mise-en-scene of a melodrama and while focusing on the narration and plot I will be dealing with the characteristic narrative features of melodrama.

\subsection{Plot and Narration}

All About My Mother (1999) is a story of a medical worker Manuela (Cecilia Roth), a middle-aged single mother living in Madrid. Her only teenage son Esteban (Eloy Azorin) is killed in a car accident while waiting for an autograph from a theatre star Huma Rojo (Marisa Paredes). Unable to find consolation, she decides to track her son's father Lola, who is a drug addict HIV-positive, transsexual prostitute, to inform Esteban's death. In Barcelona she meets up with an old friend the transvestite La Agrado (Antonia San Juan), a young pregnant nun 
Rosa (Penelope Cruz) and the actresses Huma (Marisa Paredes) and Nina (Candela Pena) whose performance they had watched together on the evening of the accident. Like a typical Hollywood melodrama the story is told in a simple linear time in chronological order and uses omniscient narration and flashbacks. Besides these features, Buckland lists the main characteristics of melodrama as follows: "(...) women-dominated narratives, the perspective of the victim, moral conflicts, omniscient narration, twists and reversals, chance events and encounters, secrets and dramatic knots which complicate the plot" (qtd in Allinson, 2001: 138). Similarly according to Thomas Elsaesser the rhetoric devices of melodrama are:

The hidden identities, misrecognitions, delayed or chance meetings, sudden reversals and climatic coups de theatre - resonate in relation to and provide a means of aesthetically organizing the experience of the city and life under capitalism, which in its geographic and temporal contiguities provides stark juxtapositions between wealth and poverty, upper and working classes, social rise and fall. (Elsaesser, 1987)

Depending on Buckland and Elsaesser's framework I will look at these elements of narration. a) Women-dominated narratives

The genre melodrama, has become synonymous with woman's film and considered as "female problems revolving around domestic life, the family, children, self sacrifice" (Doane, 1987: 3). Not because Almodovar is known as a woman's director but because mostly all the characters in the film are woman, thus All About My Mother can be regarded as a typical woman's film. It has a woman protagonist and is about the relation with her family; her son and her husband. Furthermore, melodrama is a genre in which "masculinity in general, and 'virile' masculinity in particular has been consistently qualified, questioned, impaired or castrated - unable to realize or express itself in action" (Mulvey, 1989). In this sense Jose Arroyo's comment on Almodovar's male characters might be relevant here. For him: "Male characters in Almodovar's films are often rooted in the melodramatic clichés of Spanish popular culture (...). Many of the male characters in Almodovar's films maybe interpreted as failed attempts at hegemonic notions of masculinity or a machista ideal" (Arroyo, 1998: 492). This definition of male characters in melodramas can also be followed in All About My Mother. In the film the domination of woman characters is clear. ${ }^{1}$ On the other hand one can say that there are no masculine characters at all. The male characters are either impaired or literally castrated. ${ }^{2}$ Further more, excess and hysteria are foundation elements of melodramas. They get the place of the unspoken. Hysteria is defined as a mental disorder characterized by emotional outbursts and symptoms like paralysis, amnesia that imitates physical illness. Generally hysteria is connected with the woman characters in melodramas. But in All About My Mother the amnesic and hysteric one is the father figure and that questions the power of the male figures and creates irony. As if symbolizing the Oedipal trajectory, the father is eliminated from the lives of these characters. This is also represented in the mise-en-scene of the film with a family photograph of Manuela's where Lola, (the father) is cut off. According to the patriarchal system the transvestite characters does not have a place in the symbolic order therefore as a metaphor they are cut off from the traditional family photography. Almodovar seems to create these characters as the "other" which cannot be defined in the conventional gender stereotypes to problematize the rigidly defined patriarchal subjectivities.

\footnotetext{
${ }^{1}$ The female characters can be listed as follows: Manuela (the protagonist), Manuela's son Esteban, Rosa (the pregnant nun), Rosa's hysteric mother, Rosa's amnesic father, Agrado (Manuela's transvestite friend), Lola (Manuela's travestied husband), the lesbian couple Huma and Nina (the theatre performers). Rosa is the symbol of sacrificing mother as she dies in childbirth.

2 There is Manuela's son Esteban and Rosa's new-born son. Estaban is the only character society is defining as normal teenage male figure. Ironically he is killed in the first moments of the film. He is physically eliminated from the narrative. Rosa's baby although he is a boy cannot be considered as a male as he is a new-born far from the characteristics of any gender. There are two fathers in the film; Rosa's father and Estebans's father Lola. The father figure in the film is symbolized with impotency, being powerless and incapable. Lola has become a father two times but his first son he never met is killed and to his second son he has transmitted HIV virus is miraculously survived. He could never be a power symbol for his sons as a father. Even more, he is a transvestite and looks and acts like a woman. He is symbolically castrated and lacks the whole connotations that are related with the symbol phallus. The other father figure is Rosa's father who is incable of remembering even her very own daughter. He is the symbol of melodramatic excess in the film.
} 


\section{b. Coincidences - chance meetings- encounters}

As typical in Melodrama's the film also includes lots of coincidences, chance encounters and sudden twists, and the film is full of chance encounters and there are unexpected connections between characters. ${ }^{3}$

\section{c. The hidden identities, misrecognitions}

Classic Hollywood Melodramas are marked with hidden identities and misrecognitions just like the film in question. In the beginning of the story the spectator knew that Manuela has always hid the identity of Esteban's father, as Lola is now a transvestite. Moreover Esteban dies before learning the truth of his father, which will always be a secret for him. Similarly the presences of transvestite and semi transsexual characters pose a question about the issue of hidden identities from the very start.

\section{$d$. The perspective of the victim and moral conflicts}

According to Mark Allison All About My Mother "tabs into melodrama's richest vies" (2001:139). For him, the content of the film- a mother, who has lost her son and searches the father to inform the disaster- is melodramatic. He continues in these words summarizing the moral dilemmas of each character:

The characters are almost all female, victims of circumstances, of the men in their lives, their dramas involve the moral conflicts typical of the genre: for Manuela, to follow her dead son's donated organs in a desperate attempt to be close to him then to determine to let the father know, for Agrado, to give up prostitution; for Nina, to give up drugs; for Huma, to give up Nina; for Rosa, to give birth to a baby who will be HIVpositive like her; and for Rosa's mother, to accept or reject the baby. (Allison, 2001: 139-140).

\section{e. Secrets and dramatic knots}

The film starts "with a woman with a secret" and revolves around other crucial secrets. Manuela's son is killed on the night of his 17th birthday. As a birthday present he wants from her mother to disclose the secret of his father. Manuela agrees to tell him the whole story of her relation with his supposedly dead father but unfortunately just before revealing him the truth about his father. Esteban is tragically killed in a car accident. Esteban dies without learning that his father is still alive as a travestied prostituted. Lola also does not know that he ever had a son from her former wife Manuela. Manuela always kept it as a secret from Lola that he had a son and from Esteban that his father is alive. The other secret that is revealed is that the nun Rosa is pregnant and carries the son of Lola that has passed on the HIV virus. Rosa also kept her pregnancy as a secret from her own mother.

\section{f. Circularity of the narrative}

In Classic Hollywood Melodramas the narrative structures is circular. There is always a repetition. The story compulsory returns to the beginning of the story. Similarly there is an extreme circularity in All About My Mother. As a result of melodramatic fate Rosa dies in childbirth. Before she dies she names his baby as Esteban and leaves him to Manuela to look at him. At the end when we look at Manuela situation we may see the circularity. She loses one Esteban (his own son) and gains another baby named Esteban from the same father. Ramsden states that Almodovar "cultivates a parodic model in his works, especially in his ironic treatment of melodrama and of the melodramic mode, whose conventions, again he borrow and repeat with critical as well as elevating intentions" (Ramsden, 2003: 24). As a result one can say that Almodovar get used the conventions of the genre also in his film All About My Mother.

\subsection{On Iconography in Brief}

Melodrama has been defined as a genre that reflects the tensions of domestic life and uses domestic sphere and interior space as its defining feature. In this sense when the interior and exterior spaces of the film are listed

\footnotetext{
${ }^{3}$ For example: it is "chance" that brings Rosa in contact with Lola and then with Manuela. Also it is chance that Manuela starts to work with Huma as her personal assistant (Manuela's son is killed chasing Huma for an autograph). It is interesting that Esteban is killed in his birthday and also Lola's sudden appearance towards the end of the film is an interesting encounter. One should not forget the chance meeting of Manuela and Agrado too.
} 
one can see that there is a domination of interior scenes. There are approximately 17 different scenes that take place in an interior space. On the other hand the exterior spaces used in the film are only a few. Clearly it is seen that the filmic space of the film is dominantly interior likewise the filmic space of the genre melodrama. Melodrama has been defined as a genre as having an extravagant use of mise-en-scene to embody the emotional highpoints of the drama. That is why art direction and decoration is very important. The usage of telephone and letters are typical in melodramas. In All About My Mother letter is a dominant element used. "In Classic Hollywood Melodrama, the mise-en-scene was made to work to compensate both for limited length of the films and for all those topics which could not be directly expressed in them" (Allinson, 2001:138). In this sense in All About My Mother one can follow the chaotic conflicts inside these characters are shown via the costumes and lighting. The colors of the film are used in an expressionist way especially in order to summaries the feelings of Manuela. For example the contrasting colors red and blue are mainly used to differ the atmospheric mood of the performance space of the theatre / blue is used) and Manuela's grief (red is used). When the performance of the actresses is analyzed on the contrary to superficial characters of melodrama's we get introduce characters with deep inner conflicts and complex physiological states.

\section{Performing Gender and Performing Motherhood}

To this point of the paper via very briefly analyzing the iconography and narration of All About My Mother tried to show that Almodovar is using the elements of the genre melodrama. So why is that? Why Almodovar has borrowed the conventions of melodrama and what could be the subversive intentions. In All About My Mother Almodovar is explicitly making references to other melodramas and famous film stars of the genre. The film opens with an extract from All About Eve (1950, Joseph L. Mankiewicz). Almodovar replaces "Eve" with "My Mother" in the title of his film. Signaling an inter-textual reading film starts Manuela and Estaban watching and commenting about the film All About Eve it. Also we learn that Huma started to smoke because she wanted to imitate the look of Eve, starring Bette Davis. One should also note that the film closes with a dedication to Bette Davis. From the very start Almodovar defines the paradigm of the film as a melodrama. Allinson's (2001:125) observes that in these words:

Many of the elements in his [Almodovar's] films, which exploit genre conventions also subtly undermine them; or combine usually separate conventions. Taken one step further, this 'dialogue' with genre becomes parody. Jean- Loup Bourget has observed that 'whenever an art form is highly conventional, the opportunity for subtle irony or distanciation presents itself all the more readily'. This is often exactly the strategy adopted by Almodovar.

Depending on this observation in this part of the paper I will deal how the "'dialogue' with genre becomes parody" (Bourget qtd in Allison, 2001: 125) and through parody and performance how gender and social roles are subverted. According to Linda Hutcheon "parody signals how present representations come from past ones and what ideological consequences derive from both continuity and difference" (1989: 93). Depending on her definition one can say that All About My Mother is an attempt to reread the past through a classical popular text and subvert the powers of social representations about gender and social roles. For example the character Agrado an old friend of Manuela is a half operated transsexual. With her bitchy comments, heavy make-up, extravagant costumes and not so attractive appearance she is the body of comedy. All through the film she is making a parody of femininity. The presence of Agrado provides an opportunity for a satirical comment. She is the character who makes the contradictions arising from sexual and social positioning of men and women explicit. The effect is to create a disturbing comedy and question social gender roles established in the society. So the awareness of genre conventions became parodical, which ends with a source of humor. Performing gender and some social roles are also some kind of parody too. I believe All About My Mother is a film, which is concerned with investigating performance and acting. In the film what is being subverted is gender roles and social roles; in particular the traditional "motherhood" defined by patriarchy. 
Judith Butler is a feminist critic who challenges classical feminist theory from a Foucaultian perspective. Butler with her concept "performance" makes a discussion of gender in her 1990 article "Gender Trouble: Feminisim and the Subversion of Identity". Butler argues how the categories of gender and sex are effects of power and claims that, not only gender is a social product but sex is also artificial and socially constructed. To show sex is a social construct she uses the term "performance". By the concept of performance she challenges the belief that some gendered behaviors, poses etc. are natural. According to Butler performance is a subversive act because it reveals the constructiveness of gender. Drag is an example Butler gives to explain the subversive part of performance because it discloses the role-playing aspect of gender. She uses drag to show that there is no real gender identity, which we can regard as original. Her example is particularly important in this content because Almodovar In All About My Mother uses many transvestite characters that are cross-dressing and making an open parody of femininity. They are performing how to be a woman. It shows that femininity itself is also a cultural construct. Butler writes: "the replication of heterosexual constructs in non-heteresexual frames brings into relief the utterly constructed status of the so called heterosexual original. Thus, gay is to straight not as copy is to original, but, as copy is to copy" (Butler; 1990: 31). In this sense Almodovar uses transvestite, lesbian, transsexual characters to show the constructedness of gender. Gender is in fact a kind of role-playing and as Butler says that all gender is a kind of drag. Gender is not natural and is not the essence of our identity but on the contrary gender is a kind of act, a performance, which is formed by a set of codes through repetition. Butler asks if there are no emancipatory practices of sexuality what can be subversive practices of power? According to her there can be an ability to subvert power if it is thought in terms of power and if power's own practices used against it. Excess is a good way to subvert dominant culture. In relation to this I want to give an example scene from the film that makes use of excess and make the performance of genders explicit. In this scene when the play of Huma and Nina is cancelled Agrado takes the stage in order to explain why the play has been cancelled and starts to tell her own life story to the audience. What she tells is actually the story of her body and how she has modified her body via plastic surgery. Part by part she explains how much does it cost to look like a woman. This scene totally plays with the idea of gender and how it is socially constructed and digested by the members of the society. This transvestite character in the film and the continuous regulation of her body and the resulting excessive elements can be an example how power can be subverted

Performativity is a coercive practice of power. Thus our repeating performativity of gender roles in a conventional way in our daily lives reinforces the binary opposition of man and woman. In this sense performing actors in the film questions the already there gender behaviors in the society. All About My Mother by using various kinds of characters which are transvestite, semi-transsexual, lesbians, cross-dressers, damaged father figures problematizes male - female / masculine - feminine binary oppositions. When we examine the characters of the film, it is seen that, all of them represent a marginalized aspect of their genders. By playing with the conventional gender stereotypes, Almodovar questions the subjectivity patriarchy defines via the representation of the characters. By Agrado and Lola he criticizes the normative rigid patriarchal subjectivity, which regards every difference as otherness via Rosa the passive and silenced position of woman in patriarchal society. I believe by using the excessive features of melodrama and by characterizing issues and figures in excessive ways, All About My Mother makes an ironic parody of real life to untie the gender ideology under the domination of patriarchy. Butler confronts the binary categories of sex and the assumption about the existence of a sex as prediscursive to gender. For her gender is a notion, which is independent from sex, which is in classic feminist theory thought to be a natural category. In brief, Butler claims that there is not a fixed subject behind the performances and defines gender as a "free floating artifice" which is not fixed. Performance challenges very idea of a substance beneath appearance. Performativity play part in the most ordinary affairs of everyday life. It uses an active agency to implement power and works by making one perform. It is the effect of power and repeated in order to form a truth effect.

Performance is repetition of certain acts in the terms of power. The reason one performs is because of the societal rituals, conventions that govern everyday life, which creates an illusion of a stable, monolithic gender. 
The obligation of performativity is so deeply inscribed in that one does not recognize it as an effect of power. All About My Mother is a film, which is not only concerned with investigating gender performance but also questions performing the social roles; especially motherhood as a performance. In the film the mother character Manuela acts "the mother" so many times that her acting becomes even self-conscious. In the beginning of the film Manuela acts in a simulation as the grieving mother to teach doctors how to behave the relatives of the patience when giving the bad news of dead before asking if they would consider organ donation. This is the first time she performs the mother as a play. The film unfolds and one encounters the play A Street Named Desire several times. ${ }^{4}$ After her son's death while working as an assistant of Huma she once again has the opportunity to play the role of the mother. This is the second and third time we see her perform "motherhood" in a stage. Through out the film after her son is killed we see her enact the grieving mother for real. Such an explicit reference to performing and acting is interesting in the film. Motherhood as a social role is established though repetition. In the film we continually see her act motherhood as a role, which shows the constructedness of it. The usage of excess which characterizes Classical Melodrama is taken sometimes just beyond its limit that the result becomes close to self-consciousness. We also see Nina performing the mother in the stage and at the end of the film we see Huma acting a crying mother after the death of her son in the stage. By equating motherhood with performance not only gender is questioned but also the social role of mother become self-reflective.

\section{Conclusion}

Melodrama is a genre which critics the dilemmas of modernity. Every melodrama speaks and critics its own period and its own society. Melodramas are valuable meaningful in its historical and social context as it poses a critic on it. Mulvey says that "melodrama can be seen as having ideological function in working certain contradictions through to the surface and re-presentating them in an aesthetic form" (Mulvey, 1989: 43). In this sense as a conclusion one might say that Almodovar is making a critic of his society and express socio-cultural deviation of it. In All About My Mother Almodovar's area of criticism is the obligatory gender and social roles dictated by the societies power regimes and the way he expresses this comment is hidden his usage of melodramatic conventions and his interest in performing and acting. To sum up the overall issue, the film by displaying the constructiveness of gender identity and performative side of motherhood, subverts the very idea of belonging to a role and even to a gender. Almodovar dedicated All About My Mother to mothers. As a last comment I want to quote his dedication that reveals his personal ideas about performing gender and motherhood.

To Bette Davis, Gena Rowlands, Romy Schneider...

To all actresses who have played actresses, to all women who act, to men who act and become women, to all the people who want to be mothers. To my mother.

Pedro Almodovar (All About My Mother)

\section{References}

[1] Allison, Mark. 2001. A Spanish Labyrinth: The Films of Pedro Almodóvar. London: Tauris,

[2] Arroyo, Jose. 1998. "Pedro Almodovar" The Oxford Guide to Film Studies. (eds) John Hill and Pamela Church Gibson. (491-494). New York: Oxford University Press.

\footnotetext{
${ }^{4}$ The interior spaces in the film can be listed as follows: Manuela's office in the hospital, Manuela's home in Madrid, Manuela's home in Barcelona, Esteban's room, Agrado's home, Rosa's mother's home, Rosa's working space, theatre hall, Uma's dressing room, inside the train, car and taxi, café, Rosa's doctor's office, hospital room of Rosa, hospital waiting room, the bedroom of the patient, the seminar room of the hospital etc.)

${ }^{5}$ The public spaces used in the film are: the street in front of the theatre, the view of Barcelona, the bridge where Agrado is beaten, the street Agrado and Manuela walking, in front of the hospital, graveyard and the park.

${ }^{6}$ For instance; Huma writes a letter to Manuela's son Esteban. She sends an autograph to him after his death. We see Esteban always writing to his diary. The notes he took later on works as a letter to his father because after his death and after all the secrets are revealed Lola reads the words Esteban's has written about him in his diary.

${ }^{7}$ This is an important play for Manuela because she has met her husband in this play and her son is killed after the same play. Interestingly we learn that in the past Manuela has played the mother character in A Street Named Desire.
} 
[3] Butler, Judith. Bodies That Matter: On the Discursive Limits of Sex. New York: Routledge, 1993.

[4] Butler, Judith. Gender Trouble: Feminism and the Subversion of Identity. New York: Routledge, 1990.

[5] Doane, Mary Ann; Hayward, Susan Cinema Studies: The Key Concepts New York: Routledge.

[6] Doane, Mary Ann. 1987. The Desire to Desire: The Woman's Film of the 1940's. Bloomington: Indiana University P. https://doi.org/10.1007/978-1-349-19145-1

[7] Elsaesser, Thomas. 1987. "Tales of Sound and Fury: Observations on the Family Melodrama" Christine Gledhill (ed) Home is Where the Heart Is: Studies in Melodrama and the Woman's Film. London: BFI Publishing.

[8] Gledhill, Christine. 1987. "The Melodramatic Field: An Investigation" Christine Gledhill (eds) Home is Where the Heart Is: Studies in Melodrama and the Woman's Film London: BFI Publishing.

[9] Hutchen, Linda 1989. The Politics of Postmodernism "The Politics of Parody" (92-117). NewYork: Routledge

[10] Kaplan, Ann. 1998 "Classical Hollywood Film and Melodrama" The Oxford guide to Film Studies. (eds) John Hill and Pamela Church Gibson. (272-282). New York: Oxford University Press.

[11] Neale, Steve. 2000. "Melodrama and the Woman's Film" Genre and Hollywood. 179- 204. New York: Routledge.

[12] Williams, Linda. 1998. "Melodrama Revised", Refiguring American Film Genres: History and Theory / Nick Browne (eds). Berkeley: University of California Press.

[13] Mulvey, Laura. 1989 “Notes on Sirk and Melodrama” Visual and Other Pleasures. London: McMillan.

https://doi.org/10.1007/978-1-349-19798-9_5 